\title{
1.000 års bibliotekshistorie i to bind
}

\author{
Næsten 800 sider, otte årsværk og et budget på \\ 2,6 mio. kr. Resultatet Dansk Bibliotekshistorie er \\ imponerende, og der er masser at viden at hente \\ blandt andet om samspillet mellem folke- og \\ forskningsbibliotekerne. REVY mødte to af de i alt \\ fem forfattere bag værket.
}

Tekst og fotos: Jan Kjær,

\section{Hvorfor skrive en Dansk Biblioteks- historie $i$ to tunge bind og bruge så lang tid og så store ressourcer på det?}

- Det korte svar er, at det er for at synliggøre bibliotekerne og deres kvaliteter, fortæller Nan Dahlkild.

REVY har sat ham og Steen Bille Larsen, den anden redaktør på Dansk Bibliotekshistorie, stævne i det indre København.

Hvad har været den største udfordring ved projektet?

- Vi var opmærksomme på, at 100-året for danske bibliotekslov var 2020, og det ville vi lade os animere af. Det at skrive det på den korte tid, var en stor udfordring, men også en gave. På den måde blev det ikke et evighedsprojekt at skrive at bogen, siger Steen, og Nan tager over:

Det er i sig selv en stor opgave at skrive en samlende bibliotekshistorie, der både favner Saxo, digitaliseringen og de mange forskellige typer biblioteker, men det er en enorm udfordring at samle det på så kort tid. Der ligger masser af nye fortællinger og stof og venter.

Hvad er I især blevet overrasket over i processen?

- Nogle af ildsjælene, der starter folkebibliotekerne. Det har været spændende. Den engagerede lærer Emmanuel Nielsen fra Halvrimmen i Nordjylland,

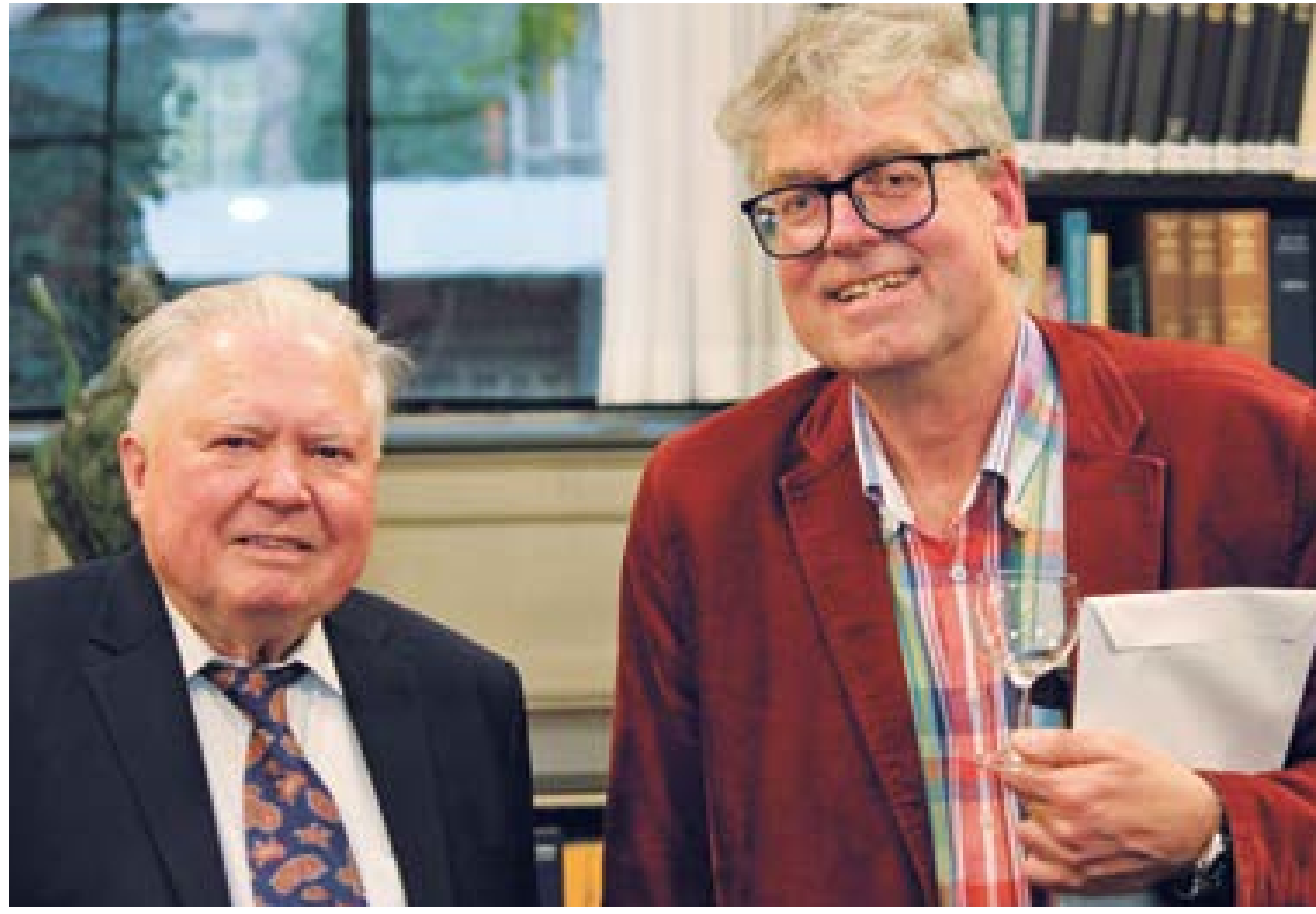

Steen Bille Larsen, medredaktør på Dansk Bibliotekshistorie: Det overrasker mig, i hvor høj grad de danske folkebiblioteker er baseret på en folkelig bevægelse. Til højre er det Christian Kaaber, en tredje bidragyder til værket.

som skænker en grund til kommunen, hvor biblioteket i 1924 blev bygget og indrettet, forklarer Nan.

- Det overrasker mig, i hvor høj grad de danske folkebiblioteker er baseret på en folkelig bevægelse. Slutningen af 1800-tallet danner klangbund for en række folkelige bevægelser som kvinde-, højskole- og andelsbevægelsen. Bibliotekssagen er ligeledes en folkelig bevægelse, forklarer Steen og tilføjer:
- Det har også overrasket mig, at udviklingen af folke- og forskningsbibliotekerne har været mere parallelle, end den kollektive bevidsthed i standen ellers foreskriver. Man gennemfører en folkebibliotekslov i 1920, og i 1927 følger en kommissionsbetænkning om forskningsbibliotekerne.

- Det betyder, at Statsbiblioteket, Landbohøjskolen og andre forskningsbiblioteker kommer til at understøtte folkebibliotekernes udlån på specialområder. 


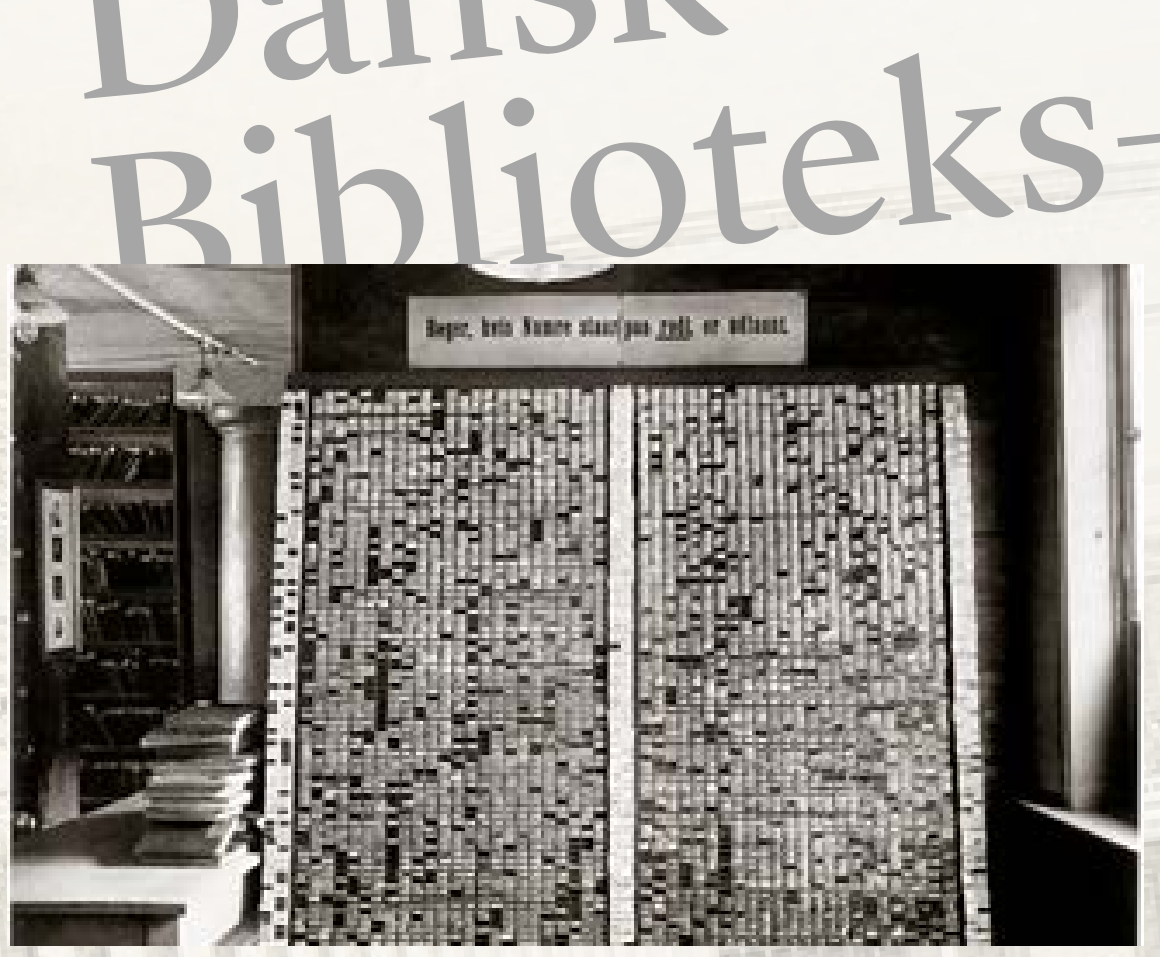

- Der kommer dybde og kvalitet i det, som folkebibliotekerne kan stille til rådighed, pointerer han.

Nan uddyber:

- Vi er stolte af samarbejdet mellem forsknings- og folkebibliotekerne. Men i den periode bliver forskningsbibliotekerne aldrig så velorganiserede som i folkebibliotekerne. De var nærmest en falanks og meget offensive. I 1964 får folkebibliotekerne så loven, som betyder de kan være kulturcentre og indoptage nye medier.

Sådan en lov får forskningsbibliotekerne ikke, og de kommer til at halte lidt bagefter i den udviklingseksplosion, der sker, der sker i 1960'erne og 70'erene. Den dag i dag er der ikke de vandtætte skotter på grund af loven om biblioteksvirksomhed fra år 2000.

\section{I skriver, at Dansk Bibliotekshistorier} mest er baseret på eksisterende forskning, og at der ikke har været tid og ressourcer til meget primærforskning. Er der nogle steder I kunne tænker jer det? - Første del af 1800-tallet er ikke særlig godt belyst. Det gælder især læseforeningerne. Og det andet er lejebibliotekerne, altså boghandlere, der også lejer bøger ud. Dem har man set meget ned på. De er aktive fra slutningen af 1700-tallet og det meste af 1800-tallet. Derefter overtager folkebibliotekerne, forklarer Steen.
Hvor ligger især "guldkornene" $i$ de to bind for Forsknings-, Fag og Uddannelsesbibliotekarerne?

- De største guldkorn ligger i udviklingen efter 2. verdenskrig, hvor forskningsbibliotekerne i højere grad bliver fagopdelt. Og det lægger grunden til loven om biblioteksvirksomhed i 2000. De er også længst fremme med it-udviklingen og begynder helt tilbage i 50'erne. De store forskningsbiblioteker
Redigeret af Nan Dahlkild og Steen Bille Larsen

Indikator - mens vi venter på, at nogen opfinder en computer. På denne indikator fra folkebiblioteket i Vestergade 23 i Aarhus kunne lånerne selv undersøge, om en bog var udlånt. Foto: Thorkild Jensen. Dansk Bibliotekshistoriske Samling. Københavns Universitet. (findes i bind l, s. 291)

har onlinekataloger på et tidspunkt, hvor de knap er begyndt på folkebibliotekerne, siger Steen, og Nan tilføjer:

- Jeg kan nævne to ting. De store forskningsbiblioteker, især Det kongelige Bibliotek og Statsbiblioteket, er gode udstillingsvirksomheder og formår at formidle deres skatte på en helt anden måde, end man gjorde før krigen.

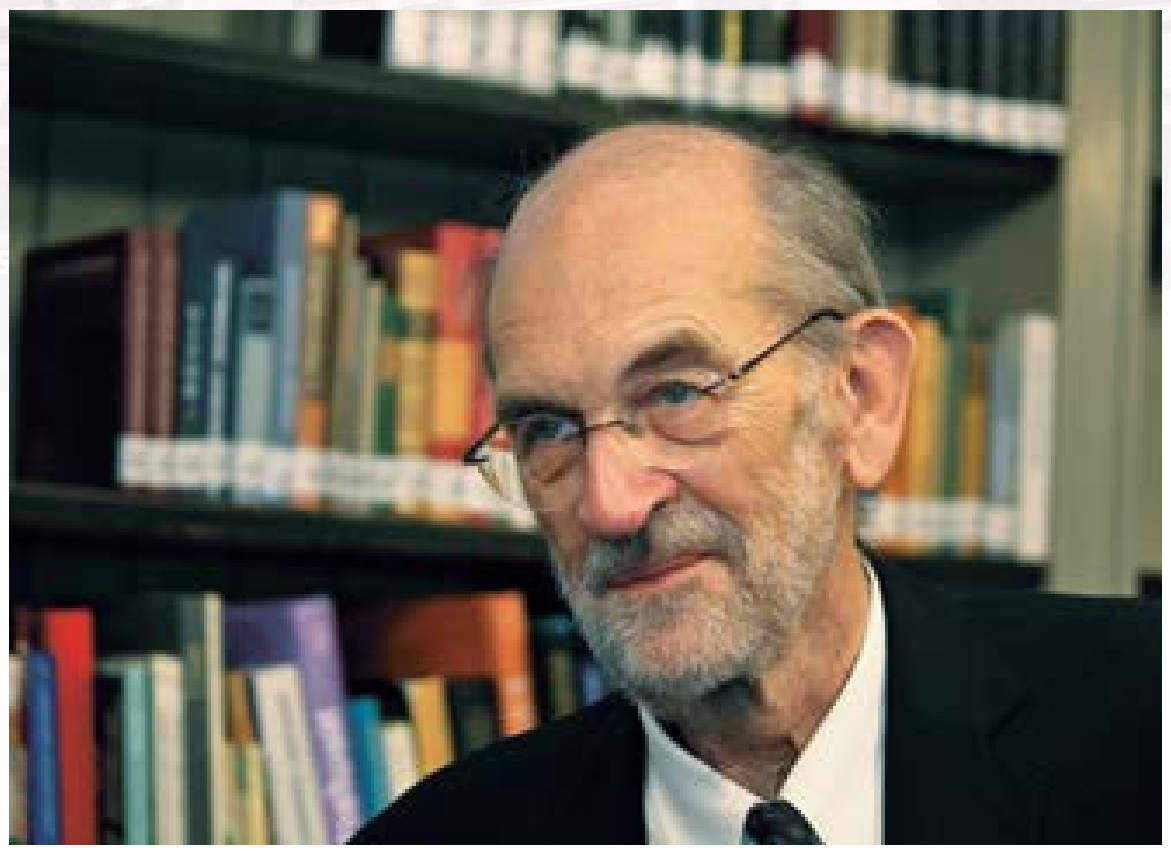

Nan Dahlkild, medredaktør på Dansk Bibliotekshistorie: Uddannelseseksplosionen i efterkrigstidens Danmark betød også en stor vækst i uddannelsesbibliotekerne. 
For det andet vokser uddannelsesbiblioteker sammen med uddannelseseksplosionen. Uddannelsesbibliotekerne spillede ikke så stor rolle før 2. verdenskrig, siger han.

Takket være it-udviklingen har forskningsbibliotekerne i dag et udlån, der er så stort, at det ville være fysisk umuligt at håndtere det.

\section{2019 udlånte man 148 millioner} enheder elektronisk. Forskningsbibliotekerne er takket være den digitale udvikling blevet en ressource for både universiteter og andre højere uddannelsesinstitutioner på en måde, de ikke har været før, uddyber Steen.
Har I været i tvivl om, det skulle udgives i bogform eller kun digitalt?

- Nej. Vi har altid set et værk, der skulle være indbydende med tekst og billeder. Den type fremadskridende fortælling er bedste til bogform, siger Steen, og Nan fortsætter: - Det er også fondenes prioritet at udgive den type værker. Men det er fint, at der senere kommer en digital udgave.

Trods de 2,6 mio. kr. er det stadig 'low budget' for så omfattende et værk.

- Der er ikke købt en kop kaffe på projektets regning, påpeger Steen.
Både redaktørerne og skribenterne er mænd.

- Vi prøvede at få kvinder med i forfattergruppen, men det lykkedes ikke. Nogle sprang fra, fordi der var andre ansættelser, som de syntes var mere interessante, siger Nan, der nu er meget spændt på, hvordan de to tykke bind Dansk Bibliotekshistorie bliver modtaget og brugt.

Han bringer en opfordring:

- Læs den!

Håbet er, at det store arbejde vil afføde debat, skabe øget interesse og inspirere til yderligere forskning på området.

\section{Forfatterne}

Nan Dahlkild: Mag.art. fra Københavns Universitet og ph.d. Lektor ved Danmarks Biblioteksskole 1977-2013 og ved Københavns Universitet fra 2013.

Jesper Vestermark Køber: Historiker (cand.mag.)

fra Københavns Universitet og ph.d. Postdoc ved Københavns Universitet og Saxo-instituttet.

Christian Kaaber: Litteraturhistoriker (mag.art.)

fra Aarhus Universitet. Har arbejdet som redaktør og journalist.

Tilknyttet Vangsgaards Antikvariat siden 2002 som antikvar, vurderingsekspert og boghistoriker.

Steen Bille Larsen: Historiker (cand.mag.) fra Københavns Universitet. Fhv. nationalbibliotekar, ansat ved Det Kongelige Bibliotek 1973-2017.

Jesper Lundby Skov: Historiker (cand.mag.)

fra Syddansk Universitet, ph.d. Postdoc ved Oslo Universitet.
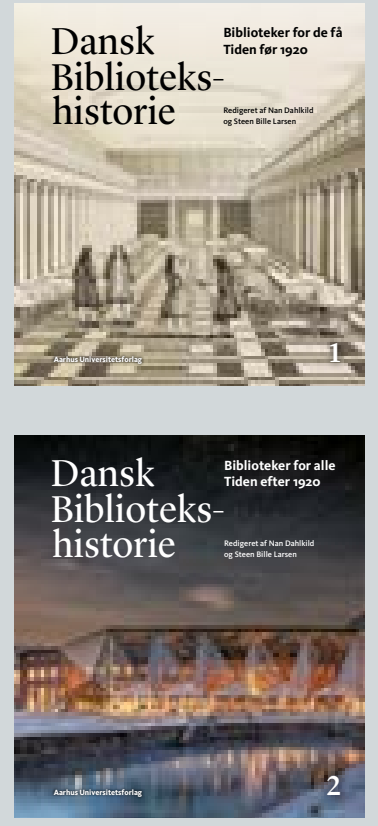

\section{Uddannelsesbiblioteket}

Et godt eksempel på den nye type biblioteker var Den Sociale Højskoles Bibliotek, der blev oprettet i København i 1963 med 'en faguddannet bibliotekar.

Biblioteket skulle skabes fra grunden og er i år 2000 vokset til at optage en hel etage i Den Sociale Højskoles nye bygning med tre ansatte, en læsesal med 25 pladser og et udlån på 13.000 bind.

(2. bind side 291)

\section{En folkebevægelse}

Biblioteket i Halvrimmen, Nordjylland Befolkningen bidrog selv med 4.000 kr. og kommunerne med 1.500 kr. Lærer Emmanuel Nielsen stillede selv midler til rådighed og frasagde sig løn for at få biblioteket til at løbe rundt.

Som en af de første i sognet købte han en bil, som primært skulle bruges som biblioteksbil til fragt af bøger, sekundært som familiebil. (2. bind side 67) 